\title{
Date Palm Tree's Defense Mechanisms from Viral Infection and Solar Ultraviolet Radiation
}

\author{
Sabah A. A. Jassim, Richard G. Limoges \\ Applied Bio Research Inc., Windsor, Canada \\ Email: prof.jassim@appliedbioresearch.co
}

Received November 22, 2013; revised December 22, 2013; accepted December 25, 2013

Copyright (C) 2014 Sabah A. A. Jassim, Richard G. Limoges. This is an open access article distributed under the Creative Commons Attribution License, which permits unrestricted use, distribution, and reproduction in any medium, provided the original work is properly cited. In accordance of the Creative Commons Attribution License all Copyrights (C) 2014 are reserved for SCIRP and the owner of the intellectual property Sabah A. A. Jassim, Richard G. Limoges. All Copyright (C) 2014 are guarded by law and by SCIRP as a guardian.

\begin{abstract}
A comprehensive review of scientific literature has uncovered no reported cases of date palm trees infected by a virus and no viral infections have been reported by farmers. In spite of the hot and humid environment they inhabit, the abundance of viral infestations in the soil, other plants and organisms surrounding the trees and the frequency of importation and transplantation of these trees into the region. Such conditions should cause the date palms to also be infected. Notably, other palm trees do not exhibit the same level of innate viral immunity that is found in date palms. The date palm tree's innate viral immunity is a virgin area in botanical research. The biological segment in date palm tree DNA that enables survival under genotoxic radiation also deserves further investigation. This field of study may enable the breeding of other economically important plants to improve desert ecology and economy, land management, agriculture and horticulture.
\end{abstract}

\section{KEYWORDS}

Date Palm Trees; Phoenix dactylifera L.; Antiviral; Defense Mechanisms; Innate Immunity; Solar Ultraviolet Radiation

\section{Introduction}

The date palm is very exacting in its climatic requirements. The successful cultivation of date palms requires desert climates which offer unique conditions and certain fundamental requirements for crop survival and growth.

The desert environment is toxic for many plants. The extreme heat and intensity of the year-round solar radiation can quickly desiccate most plants. In addition, numerous plants and hybrids have been carelessly transplanted between these regions over the centuries. These relocations were often accompanied by unanticipated invading species and pathogens which have made horticulture even more challenging in desert ecosystems.

One of the challenges in compiling research for this article is the surprising lack of research material or literature regarding viral diseases as related to date palm trees.

This article will shed light on the date palm's perplexing tolerance to viral infections and for the high desert radiation levels. This could represent a platform for further investigation on this important desert plant that has survived for thousands of years in harsh desert conditions. Date palms have provided nutrition for desert inhabitants for these millennia and yet these mysteries and their potential for enriching desert ecosystems have until now gone mostly unreported.

A greater understanding of these scientifically significant features of the date palm tree should permit the application of modern day methods to adapt and assign these traits to other economically significant crops, thus enabling increased agricultural productivity in desert ecosystems.

\section{Date Palm Tree}

Phoenix dactylifera $L$. (date palm) is a palm in the genus Phoenix, a monocotyledonous woody perennial belonging to the Arecaceae family, which comprises 200 genera and 3000 species and is cultivated for its sweet edible 
fruit [1]. Although its place of origin is unknown because of long term cultivation, it probably originated from lands around modern day Iraq or "Mesopotamia” [2]. It is one of mankind's oldest cultivated plants and it has been used as a source of food for 6000 years. The date palm is a key element of the oasis ecosystem. It is grown extensively in arid and semi-arid regions of the world from latitude North $10^{\circ}$ (Somalia) to $39^{\circ}$ (Turkmenistan, and Elche in Spain), with the most favourable zones between $24^{\circ}$ and $34^{\circ}$ (Algeria, Egypt, Kingdom of Saudi Arabia, Iraq, Morocco, Libya, Tunisia, etc.) [3].

The number of date palms in the 21 date-producing countries of the world amount to about 100 to 120 million with a total production of dates approaching 5.4 million tons [4,5]. This estimate has been increased in 2010 to around 9 million tons [6]. The Arab countries account for $70 \%$ of the world's date palms and are responsible for $67 \%$ of global date production [5].

\section{Innate Viral Immunity as a Plant Defence Mechanism}

There are approximately 450 species of plant-pathogenic viruses, which cause a range of diseases [7]. They often cause a loss of yield, yet it has not been economically viable to try to control them. Plant viruses are often spread from plant to plant by organisms, known as vectors. These are normally insects, but some fungi, nematode worms and single-celled organisms have also been shown to be vectors. When control of plant virus infections is considered economical, such as for perennial fruits, efforts are concentrated on killing the vectors and removing alternate hosts such as weeds.

Innate immunity is an ecological adaptation mechanism that helps to protects plants, animals and humans from a wide range of pathogens. Invading pathogens are recognized by diverse pattern recognition receptors [8]. In specific cases, plants have evolved resistance $(\mathrm{R})$ genes that mediate intracellular recognition of effector proteins [9], which results in effector triggered immunity (ETI) [8]. ETI is a rapid and high-amplitude output, considered to be an amplified version of pattern-triggered immunity [8]. The ETI signalling cascades often lead to hypersensitive response (HR) and programmed cell death that locally counteracts pathogen attack and progression [9].

Most plant $\mathrm{R}$ proteins belong to the nucleotide binding site-leucine rich repeat (NB-LRR) family. Plant NBLRRs are classified into two main classes: CC-NB-LRRs with the N-terminal coiled-coil (CC) domain and TIRNB-LRRs with the N-terminal Toll-interleukin-1 receptor (TIR) domain, which have specialized functions in immune responses [8]. However, there are more than 20 $\mathrm{R}$ genes reported from diverse plant species conferring race-specific resistance to viral infection (9). Plant $R$ proteins functioning depends on the chaperon complex that includes SGT1 (Suppressor of G2 allele of skp1), HSP90 (Heat-shock protein 90) and RAR1 (Required for Mla12 resistance). It has been hypothesized that this complex might facilitate a conformational change of $\mathrm{R}$ proteins inducing the immune signalling after recognition of pathogen effectors or modified host proteins targeted by pathogen effectors [8]. Different $\mathrm{R}$ genes from distantly related plant species suggest that these motifs are structural and/or functional domains involved in determining resistance responses to diverse groups of plant pathogens [9].

These are mechanisms created by plants to stop the infection from spreading [9]. RNA interference is also an effective defence in plants $[7,8]$. When they are infected, plants often produce natural disinfectants that kill viruses, such as salicylic acid, nitric oxide, and reactive oxygen molecules [7]. The previously unpublished data of Sabah Jassim found that $\mathrm{Ca}^{2+}$ increased in wheat after the plant recovered from an artificial infection with a mosaic virus. There is a transient $\mathrm{Ca}^{2+}$ signature change upon infection with a virulent pathogen that is required for effective defence [10]. Changes in ion fluxes are believed to activate several kinase cascades, for example, $\mathrm{Ca}^{2+}$ binding by calcium-dependent protein kinases, triggers phosphorylation relays [10].

The interactions between plants and microorganisms are complex and several relationships have been described. A given microorganism can only infect selected plant species. If a microorganism cannot infect a plant species, the plant species is described as a non-host. Failure to infect a non-host species is usually due to basal defences, which include physical barriers to infection such as the cell wall, waxy cuticle and bark, as well as the production of several antimicrobial compounds [7].

Plant's resistance $(\mathrm{R})$ genes confer resistance only to specific pathogens. For example, the Arabidopsis thaliana RCY1 gene confers resistance to the Y strain of $\mathrm{cu}-$ cumber mosaic virus (CMV), but not to the $\mathrm{O}$ strain. When the $\mathrm{Y}$ strain of CMV infects RCY1-containing plants, a defence response is initiated, which restricts the virus to the infection site and prevents disease. The virus is an avirulent pathogen on these resistant plants and this is termed an incompatible interaction. The pathogen molecule that specifically elicits R-protein-mediated responses is the avirulence (Avr) determinant. Avr proteins are usually necessary for successful infection and are almost invariably virulence factors in a susceptible host [7].

\section{Date Palm Tree Innate Viral Immunity}

There are numerous reports published in peer reviewed/ scholarly journals regarding the red palm weevil (RPW), Rhynchophorus ferrugineus, or fungal diseases [3-5,11, 12 ] but surprisingly there is no reported evidence or lit- 
erature of a viral infection in date palm trees. The results of Jassim and Naji [1] have also shown a strong antiviral activity was obtained from various varieties of date palm pits of Phoenix dactylifera L. This supports the hypothesis that date palm trees have an enhanced and novel innate viral immunity. Since this phenomenon has not yet been reported upon by scientists, it represents a potential new direction for scientific research pertaining to desert ecosystems.

\section{Date Palm Tree Solar Ultraviolet Radiation (SUR) Defense Mechanisms}

Virtually nothing was previously known about the effects of SUR on plants [13]. The knowledge database is principally limited to the effects on agricultural crops; little is known of the effects of SUR in other natural ecosystems such as forests, meadows, savannas, tundra and alpine areas [14]. In general, SUR deleteriously affects plant growth; reducing leaf size and limiting the area available for energy capture [15]. However, solar radiation (wavelengths of $400-700 \mathrm{~nm}$ ) is also used to provide the energy for photosynthesis, the process by which plants make sugars and carbohydrates.

As previously noted, date palm trees are grown extensively in arid and semi-arid regions of the world from latitude North $10^{\circ}$ (Somalia) with most favourable zones are between $24^{\circ}$ and $34^{\circ}$, which represent large desert areas, wherein SUR is at high levels for most of the year [4]. In other words, date palm trees thrive where most other plants would not survive.

Solar radiation is also an important parameter for photosynthesis and evapotranspiration [16]. These two phenomena are dependent not only on the intensity of radiation but also on the distribution of intercepted radiation within the canopy [16]. Plants intercept both direct and diffuse sunlight. The upper leaves receive solar incident radiation as well as radiation reflected by the soil surface, while the lower leaves intercept a small portion of direct radiation [16]. Diffuse radiation therefore, becomes more significant in the lower leaves due to radiation transmitted and reflected from the leaves and the soil surface.

The solar radiation spectrum is divided into regions, each with its own characteristic properties [17]. It is well-known that solar radiation transmitted by the leaves is predominantly infrared [16]. Essentially, the entire visible light spectrum is capable of promoting photosynthesis, but the regions from 400 to 500 and 600 to 700 $\mathrm{nm}$ are the most effective [16,17]. In addition, pure chlorophyll has a very weak absorption, between 500 and 600 $\mathrm{nm}$. The accessory pigments complement the absorption of light in this region, supplementing the chlorophylls $[16,17]$.

- 620 - $700 \mathrm{~nm}$ (red): greater absorption bands of chlorophyll;
- 510 - 620 nm (orange, yellow-green): low photosynthetic activity;

- 380 - $510 \mathrm{~nm}$ (purple "violet”, blue and green): the most energetic, with strong absorption by chlorophyll;

- $380 \mathrm{~nm}$ (ultraviolet): germicidal effects, even lethal $<260 \mathrm{~nm}$.

It is important to mention that the UV-A (320 nm to $400 \mathrm{~nm}$ ) and UV-B (290 nm to $320 \mathrm{~nm}$ ) are able to penetrate Earth's atmosphere $[18,19]$. According to Mason [20], the growth of a date palm is inhibited by light rays at the violet $(380 \mathrm{~nm})$ and yellow $(510 \mathrm{~nm})$ end of the spectrum, but enhanced by rays at the other end of the spectrum i.e. red light (620 - $700 \mathrm{~nm})$. These latter rays are most active in promoting photosynthesis. This suggests that UV radiation UV-A (320 nm to $400 \mathrm{~nm}$ ) and UV-B (290 nm to $320 \mathrm{~nm}$ ) are of greatest concern to date palm trees since the genotoxic potential of UV is linked to its ability to provoke direct DNA damage [19]. The damage caused by UV-B includes direct formation of thymine dimers or other pyrimidine dimers and doublestrand DNA breakage [19,21]. In general, the SUR levels have increased by 6\% on average since 1979 and are projected by some estimates to increase to $650 \%$ by 2065 in mid-latitude cities [22].

Nevertheless, Phoenix species have tolerated these harsh SUR levels for over 6000 years and in fact demand full sun where "shading out" can result in decline or death to the plant in desert areas. These conditions are essential for date palm trees to have a normal complete and full productive cycle, i.e. to bear fruit. Some desert plants appear to be quite resistant to increased UV irradiation and the differential susceptibility of plants to UV stress is clearly an important factor in their competitive relationships in these terrestrial ecosystems.

The study of Sham and Aly [23] included a diverse array of plants to determine the involvement of the enzyme desaturase in omega-3 fatty acid synthesis. Their results suggest that desaturases play a significant role in stress response in selected plant species such as date palm. The above findings lead to the hypothesis that date palms possess unique biological mechanisms allowing them to cope with genotoxic radiations while preventing cellular destruction and/or DNA mutations.

It will be instrumental to discover how date palm trees maintain a productive cycle under such genotoxic solar radiation and very high temperatures $\left(60^{\circ} \mathrm{C}\right.$ to $\left.65^{\circ} \mathrm{C}\right)$ which are lethal to non-adapted plants in the desert. It is well known that excessive sunlight and heat stress induce membrane damage and photoinhibition that leads to reactive oxygen species accumulation, in which the light causes production of excess excitation energy in the photosynthetic reaction centres. The direct accumulation of a variety of reactive oxygen species along with heat stress denatures proteins and causes lipid peroxidation [24]. 
Years of rigorous research have demonstrated that the abiotic stress of UV irradiation affects various cellular processes in plants and induces alterations in gene expression programs in order to activate the plant's defense mechanisms for survival. These include a wide range of stress-responsive genes, encoding transcription factors and functional proteins whose transcription is altered during abiotic stress [25].

In general, plants show different levels of radiation tolerance, one can even find genotypic differences in tolerance levels. Low levels of radiation promote plant growth, and also promote accumulation of secondary metabolites in plant vacuoles. Thus the date palm tree could provide us with interesting information and compounds for adapting plants for tolerance to radiation. Providing protection from biotic and abiotic stresses has applications for other crops as well [26].

\section{Discussion and Conclusions}

Date palm trees display innate immunity mechanisms against all known plant viruses. This phenomenon has not yet been reported upon by scientists. This field of study could provide many other answers, and uncover the profiles of secondary metabolites, which are accumulated as a result of different types of stresses. Innate immunity is found in all plants against some viruses, but not usually against all viruses. The fact that not a single case of viral disease has been reported for date palm trees leads to the hypothesis that the date palm tree has developed a superior innate immunity which has evolved under harsh desert solar radiation over thousands of years. Viral-host interactions are also disrupted by solar and ultraviolet radiations [19]. Thus the solar ultraviolet radiation prevalent in desert ecosystems may also help to inactivate the viral infection and proliferation in host cells of date palm trees.

Current technology will enable genetic analysis of viral R-genes in male and female and among different types of date palm trees, allowing the discovery of consistent differences between them if any. It will be equally important to establish their genetic map using broad brush "light sequencing" techniques.

This points to a new research direction for date palm trees as the precursor for using viral R-genes coded proteins to develop genotypes that produce plant compounds that act as a RPW repellent or to treat challenging phytoplasma diseases of date palms. This technology may also be used to produce other economically important crops which share the novel date palm's innate viral immunity.

This study may also uncover the novel date palm genes, the "extremophiles-SUR protein" or oil based component that enables the date palm trees to grow normally despite the genotoxic UV radiations in the desert.

This may lead researchers to an enhanced understanding of the significance of the date palm's innate viral immunity and tolerance to solar ultraviolet radiation, leading to the development of new plant pharmacy technology or to designing other plants that can survive the harsh desert conditions.

\section{REFERENCES}

[1] S. A. A. Jassim and M. A. Naji, "In Vitro Evaluation of the Antiviral Activity of an Extract of Date Palm (Phoenix dactylifera L.) Pits on a Pseudomonas Phage," Evidence-Based Complementary and Alternative Medicine, Vol. 7, No. 1, 2010, pp. 57-62.

http://dx.doi.org/10.1093/ecam/nem160

[2] J. Morton, “Date,” In: J. F. Morton and F. L. Miami, Eds., Fruits of Warm Climates, Purdue University, USA, 1987, pp. 5-11.

[3] A. F. Zabar and A. Borowy, "Cultivation of Date Palm in Iraq,” Annales Universitatis Maria Curie Sklodowsks, Lublin, Polonia, Vol. 22, No. 1. 2012.

http://wydawnictwo.up.lublin.pl/annales/Horticultura/201 2/05Zabar.pdf

[4] A. Zaid and E. J. Arias-Jiménez, "Date Palm Cultivation,” Food and Agriculture Organization, Plant Production and Protection, Paper 156, Rome, 2002, p. 292. http://www.fao.org/docrep/006/Y4360E/y4360e00.htm

[5] L. I. El-Juhany, "Degradation of Date Palm Trees and Date Production in Arab Countries: Causes and Potential Rehabilitation,” Australian Journal of Basic and Applied Sciences, Vol. 4, No. 8, 2010, pp. 3998-4010.

[6] Food and Agriculture Organization, "Statistical Databases,” 2010. http://faostat.fao.org

[7] J. L. Soosaar, T. M. Burch-Smith and S. P. DineshKumar, "Mechanisms of Plant Resistance to Viruses," Nature Reviews Microbiology, Vol. 3, No. 10, 2005, pp. 789-798. http://dx.doi.org/10.1038/nrmicro1239

[8] A. S. Zvereva and M. M. Pooggin, "Silencing and Innate Immunity in Plant Defense against Viral and Non-Viral Pathogens,” Viruses, Vol. 4, 2012, pp. 2578-2597. http://dx.doi.org/10.3390/v4112578

[9] S. P. Dinesh-Kumar, W.-H. Tham and B. J. Baker, "Structure Function Analysis of the Tobacco Mosaic Virus Resistance Gene N," The Proceedings of the National Academy of Sciences USA, Vol. 97, No. 26, 2000, pp. 1478914794. http://dx.doi.org/10.1073/pnas.97.26.14789

[10] J. J. Rudd and V. E. Franklin-Tong, "Unravelling Response Specificity in $\mathrm{Ca}^{2+}$ Signalling Pathways in Plant Cells,” New Phytologist, Vol. 151, No. 1, 2001, pp. 7-33.

[11] M. A. Triki, A. Zouba, O. Khoualdia, O. Ben Mahamoud, et al., "Maladie Des Feuilles Cassantes' or Brittle Leaf Disease of Date Palms in Tunisia: Biotic or Abiotic Disease?” Journal of Plant Pathology, Vol. 85, No. 2, 2003, pp. 71-79.

[12] A. A. Abul-Soad, W. A. Maitlo, G. S. Markhand and S. M. Mahdi, "Date Palm Wilt Disease (Sudden Decline 
Syndrome) in Pakistan, Symptoms and Remedy," The Blessed Tree, Khalifa International Date Palm Award, UAE, 2011, pp. 3-4.

[13] A. H. Teramura, "Overview of Our Current State of Knowledge of UV Effects on Plants,” In: J. G. Titus, Ed., Effects of Changes on Stratospheric Ozone and Global Climate, US Environmental Protection Agency and United Nations Environmental Program, Washington DC, Vol. 1, 1986, pp. 165-173.

[14] M. Tevini and A. H. Teramura, "UV-B Effects on Terrestrial Plants," Photochemistry and Photobiology, Vol. 50, No. 4, 1989, pp. 479-487. http://dx.doi.org/10.1111/j.1751-1097.1989.tb05552.x

[15] B. Diffey, "Solar Ultraviolet Radiation Effects on Biological Systems," Physics in Medicine and Biology, Vol. 36, No. 3, 1991, pp. 299-328. http://dx.doi.org/10.1088/0031-9155/36/3/001

[16] J. Monteith, "Light Interception and Radioactive Exchange in Crop Stands," Agronomy and Horticulture, Faculty Publications, Agronomy and Horticulture Department, Paper 185, University of Nottingham, Loughborough, 1969.

http://digitalcommons.unl.edu/agronomyfacpub/185

[17] C. Campillo, R. Fortes and M. D. H. Prieto, "Solar Radiation Effect on Crop Production,” In: E. B. Babatunde, Ed., Solar Radiation, 2012.

http://www.intechopen.com/books/solar-radiation/solar-ra diation-effect-on-crop-production

[18] S. Clancy, "DNA Damage and Repair: Mechanisms for Maintaining DNA Integrity,” Nature Education, Vol. 1, No. 1, 2008.

http://www.nature.com/scitable/topicpage/dna-damage-re pair-mechanisms-for-maintaining-dna-344

[19] S. A. A. Jassim and R. G. Limoges, "Impact of External Forces on Cyanophage-Host Interactions in Aquatic Ecosystems,” World Journal of Microbiology and Biotechnology, Vol. 29, No. 10, 2013, pp. 1751-1762. http://dx.doi.org/10.1007/s11274-013-1358-5

[20] S. C. Maso, "Partial Thermostasy of the Growth Centre of the Date Palm," Journal of Agricultural Research, Vol. 31, No. 5, 1925, pp. 415-453.

[21] Y. Miyamura, S. G. Coelho, K. Schlenz, J. Batzer, et al., "The Deceptive Nature of UVA-Tanning versus the Modest Protective Effects of UVB-Tanning on Human Skin,” Pigment Cell and Melanoma Research, Vol. 24, No. 1, 2011, pp. 136-147. http://dx.doi.org/10.1111/j.1755-148X.2010.00764.x

[22] P. A. Newman, L. D. Oman, A. R. Douglass, E. L. Fleming, et al., "What Would Have Happened to the Ozone Layer if Chlorofluorocarbons (CFCs) Had Not Been Regulated?” Atmospheric Chemistry and Physics, Vol. 9, No. 6, 2009, pp. 2113-2128.

http://dx.doi.org/10.5194/acp-9-2113-2009

[23] A. Sham and M. A. M. Aly, "Bioinformatics Based Comparative Analysis of Omega-3 Fatty Acids in Desert Plants and their Role in Stress Resistance and Tolerance," International Journal of Plant Research, Vol. 2, No. 3, 2012, pp. 80-89. http://dx.doi.org/10.5923/j.plant.20120203.06

[24] C. E. Vickers, J. Gershenzon, M. T. Lerdau and F. A. Loreto, "A Unified Mechanism of Action for Volatile Isoprenoids in Plant Abiotic Stress," Nature Chemical Biology, Vol. 5, No. 5, 2009, pp. 283-291. http://dx.doi.org/10.1038/nchembio.158

[25] T. Hirayama and K. Shinozaki, "Research on Plant Abiotic Stress Responses in the Post-Genome Era: Past, Present and Future,” The Plant Journal, Vol. 61, 2010, pp. 1041-1052. http://dx.doi.org/10.1111/j.1365-313X.2010.0 $\underline{4124 . \mathrm{X}}$

[26] A. K. Shanker and B. Venkateswarlu, "Abiotic Stress in Plants-Mechanisms and Adaptations," InTech Open Access Publisher, Croatia, 2011. http://www.academia.edu/1129311/Abiotic_Stress_in_Pla nts___Mechanisms_and_Adaptations 